\title{
A CENZÚRA ESZTÉTIKÁJA
}

\section{Árva lányok otthona Iránban}

Erkélyek felhajtott „hidzsábbal” Fotó: Aidin Gilandoost
Hagyományok, szokások, vallási elő́rások napjainkban egyre inkább háttérbe szorulnak világszerte, ami nagyrészt az emberek és az információ szabad mozgásának tudható be. Az utóbbi évtizedekben egyfajta modern népvándorlásnak vagyunk szemtanúi, ahol nem csak az emberek, hanem az alkotó gondolatok is egyik kontinensről a másikra vándorolnak, ami egyre fontosabb a kreatív iparágak számára. Legtöbbször a problémák eltérő megközelítése eredményez új megoldásokat, amihez elengedhetetlen az alkotó együtt gondolkodás, a nézetek ütköztetése, diszciplínák közötti átjárhatóság. Kutatások igazolták például, hogy míg a nyugati emberek magára

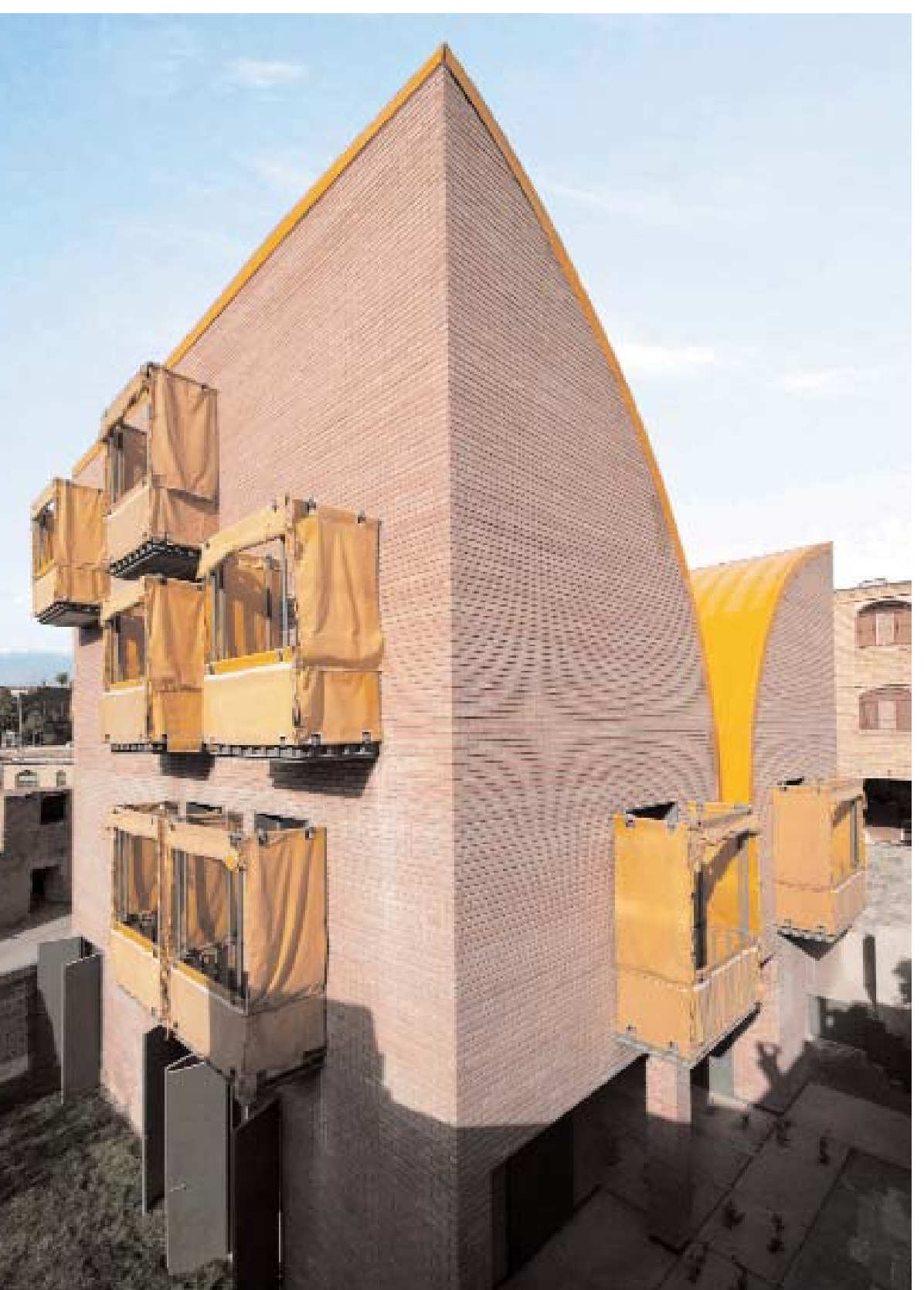

az objektumra koncentrálnak elsősorban, keleti társaik a kontextusra érzékenyebbek. [1]

Azon régiókban, ahol a hagyományok tisztelete a hétköznapok kötelező részét képezi, különösen nagy jelentőséget kaphat a befogadó környezet megértése. Iránban például az iszlám vallás számos előírásának betartására a törvény kötelez, az attól való eltérést szigorúan szankcionálják, ami az építészeti alkotó folyamatra is hatást gyakorolhat. Nem az építészeti megjelenésbe való beleszólásról van szó, sokkal inkább a hétköznapi élet szabályainak betartása érdekében kell az építészeknek különösen körültekintőnek lenniük, megérteniük a tágabban értelmezett kontextust.

Az iráni ZAV Architects építészeit lányok számára építendő árvaház tervezésével bízta meg Khansar városában dr. Ahmad Maleki, egy idős filozófus. Az árván maradt gyermekek gondozása a fejlődő világban általánosságban is gondot jelent, mivel a népességszaporulat alakulása nem ösztönzi a családok befogadókészségét, így a szülők nélkül maradt gyerekek tömege nevelkedik az utcán, és az állam csak kevés országban érzi feladatának a velük való törődést. A hontalanul felnövő, a társadalomból kirekesztett gyerekek ki vannak téve az alvilág emberkereskedelemmel, prostitúcióval foglalkozó köreinek. Befogadó otthon nélkül jövőjük bizonytalan.

Khansar Teherántól 280 kilométerre délre található, bővizű forrásai és történelmi épületi miatt sokan látogatják. Mivel a város nagymértékben támaszkodik az idegenforgalomból származó bevételekre, a megrendelő azt akarta, hogy az árvák élőhelye a város történelmi müemlékei közé kerüljön, anélkül hogy megzavarná a környezet építészeti integritását. Az építészek a ,jól bevált” bentlakásos gyermekotthon helyett egy családias lakóközösség gondolatát fogalmazták meg, amely az elhelyezkedéséből adódóan az azt körülvevő lakóházakéhoz hasonló körülmények között nyújthat menedéket hátrányos helyzetű lakóinak.

A cél az volt, hogy eltávolodjanak attól, hogy a lányok állandó felügyelet alatt legyenek, ehelyett inkább a normálishoz közeli életet élhessenek Khansar introvertált társadalmi környezetében. A felvetés szerint a lányoknak mindössze egy olyan otthonra van szükségük, amely kedvük szerinti és büszkék lehetnek rá. Egy igazi otthon- 


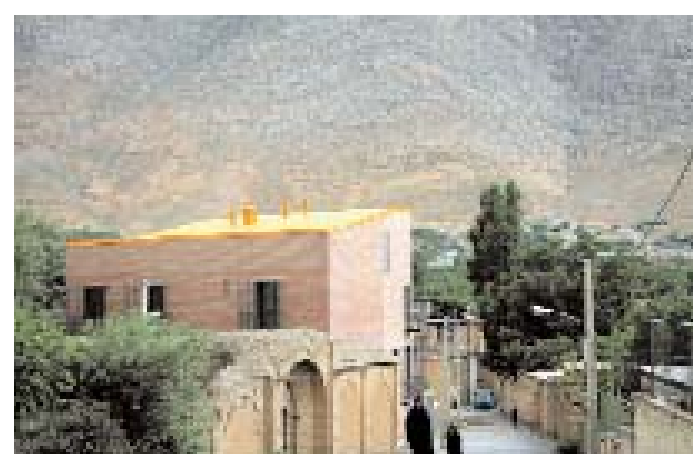

ra, szemben a kollégiumok börtönszerű, fegyelemre és szabályokra épülő légkörével.

Khansar rendkívül konzervatív hely, az állami tisztviselők kétségeket fogalmaztak meg a projekttel szemben. Úgy vélték, jobb lenne ugyanazt az íratlan törvényt követni, amelynek alapján az ország összes árvaháza múködik, miszerint az összes lány egy közös szobában él és alszik, ugyanazon az emeleten, ahol az igazgató. Arra a kérdésre azonban, hogy az összes lány egy szobában történő elszállásolása gyakorlati szempontból fontos-e, vagy esetleg egyfajta ellenőrzést, felügyeletet tesz könynyebbé, senki nem tudta a választ, így végül elfogadták a megszokottól való eltérést.

Az Iránban újszerū koncepció azonban kihívást is jelentett a tervezők számára. Például a perzsa és iszlám hagyományban lévő lakóházak a befelé fordulás elvét követik. Ez azt jelenti, hogy a ház külseje (biruni) viszszafogottabb és sokkal kevésbé díszes, mint a ház belseje (andarun). A külsőt többnyire egyszerü geometriai elemekből formálják, hogy leképezze a szent világ harmóniáját. Az építészek a befelé fordulás elvét követve zárt homlokzatot terveztek, mivel az iszlámban kötelesség az idegenek szeme elől védeni a ház lakóit. A magánélet feltételei megteremtésének szükségessége még nagyobb jelentőséggel bír ott, ahol kizárólag nők élnek, így a falak is „óvják” a lányok tisztaságát. Az épület íveket formáló falaival körbezárt udvara lehetővé teszi a lányok számára, hogy érezzék a napfényt, a szelet a bőrükön és a hajukon az illetéktelenek pillantásától való aggodalom nélkül. Egy másik hagyományos építészeti elem a sekély vizű medence az udvaron, transzcendens jelentéstartalommal. A fák és gyógynövények buja kertjében elhelyezett vízfelület az iráni kultúra képzeletvilágában szimbolikusan átlépést biztosít a kozmikus világba. A medence vize tükrözi az égboltot, szellemi dimenziót nyit meg a szemlélődő előtt. A gyerekek szeretik ezt a területet a csatlakozó játszóhellyel együtt, segít nekik átvészelni a nyári forróságot.

A tipikus perzsa házban a körbezártság által kínált vizuális védelmi pajzs a családtagok közötti szolidaritás érzetét is erősíti. Ez az árvaotthonban is érezhető, a lányok családtagként utalnak egymásra, így könnyebben mutatják ki szeretetüket társaik és igazgatójuk felé. A gyakorlatban is igazolódik az a felvetés, miszerint az árva gyerekek közösséghez tartozásának kialakulását, pszichológiai fejlődését segíti a jól strukturált térszervezés. [2]

Az épület földszintjén egy csoportos összejövetelekre tervezett nyitott terü társalgó található, míg az első emeleten a közös konyha, a gépészeti helyiség és az igazgató lakosztálya kapott helyet. A következő szinten lévő hat, erkélyes hálószoba mindegyike legfeljebb 15 hét és tizenöt év közötti lányt fogad be. Az épület külseje és belseje közötti kontinuitásról ugyanazon helyi anyagok, elsősorban kezeletlen tégla és fa felhasználása gondoskodik. Az egyszerű anyaghasználat ellenére a természetes fény beengedése és az átgondolt térrendszer eredményeként a terek otthonosak és meleg hangulatúak. A hálószoba az a hely, ahol a gyerekek az önállóságot és függetlenséget érzik, és ahol a fontos és személyes beszélgetések zajlanak, a belőlük nyíló erkélyek pedig gyakran a relaxálás, az önmagukat kereső távolba révedés helyszínei.
É pít és z:

\section{Z A V}

Architects

\section{A város idővonalába simulva}

Fotó: Soroush Majidi

\section{Hegyeket idéző ívek}

Fotó: Soroush Majidi

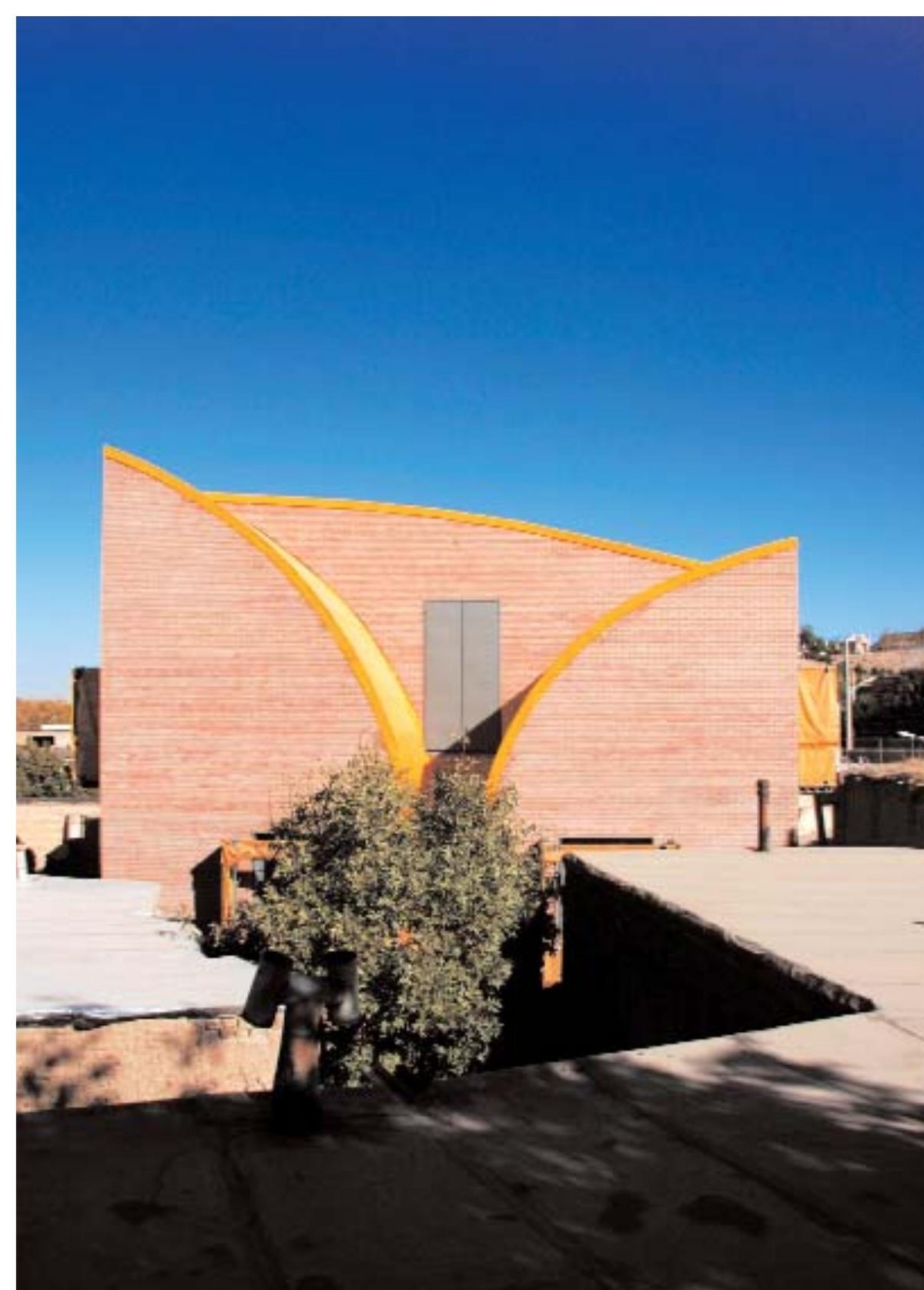




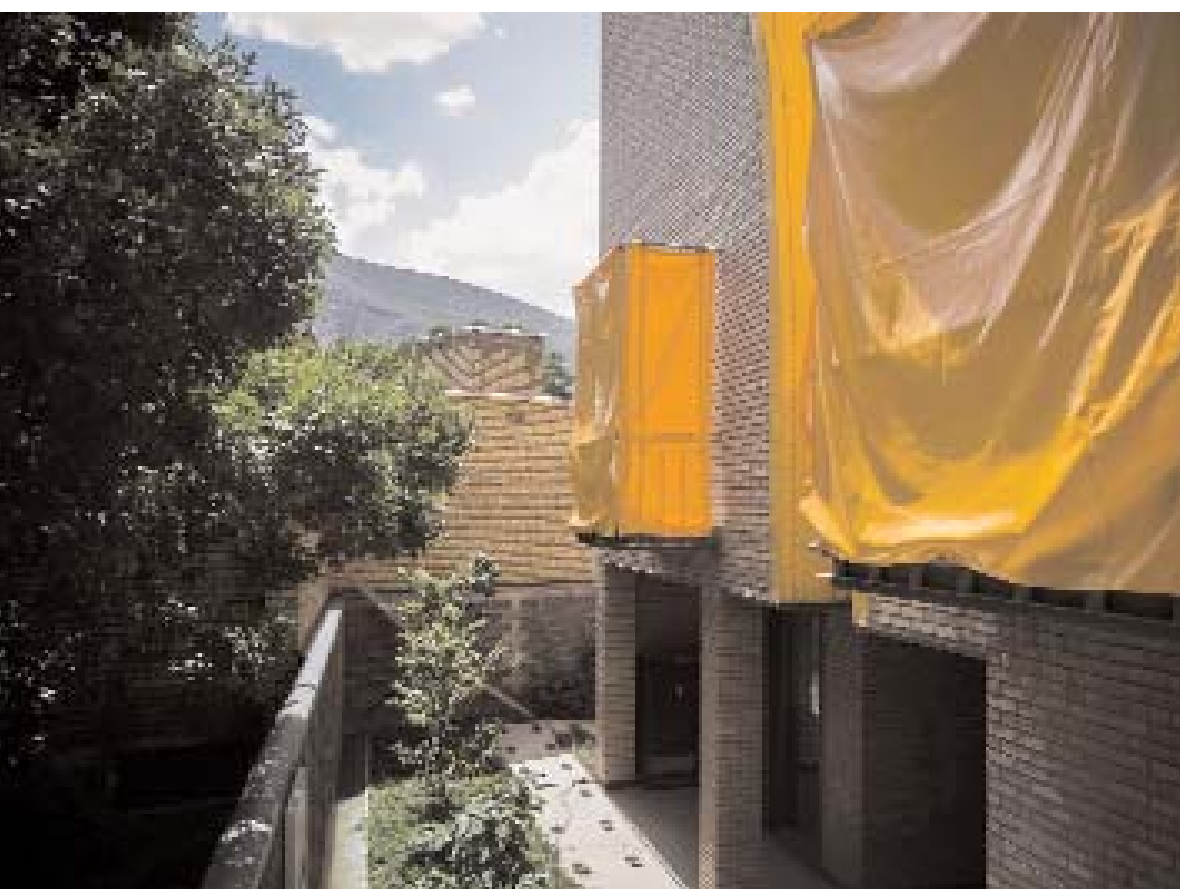

Színes ponyvák mint a cenzúra különös megnyilvánulása

Fotó: Tahmine Monzavi

Az irániak azt mondják, hogy két életük van: az egyik a házon belül, ahol azt teszik, amihez kedvük van, a másik azon kívül, ahol magas szinten kell betartaniuk az illendőség szabályait. Iránban az otthon olyan hely, ahol

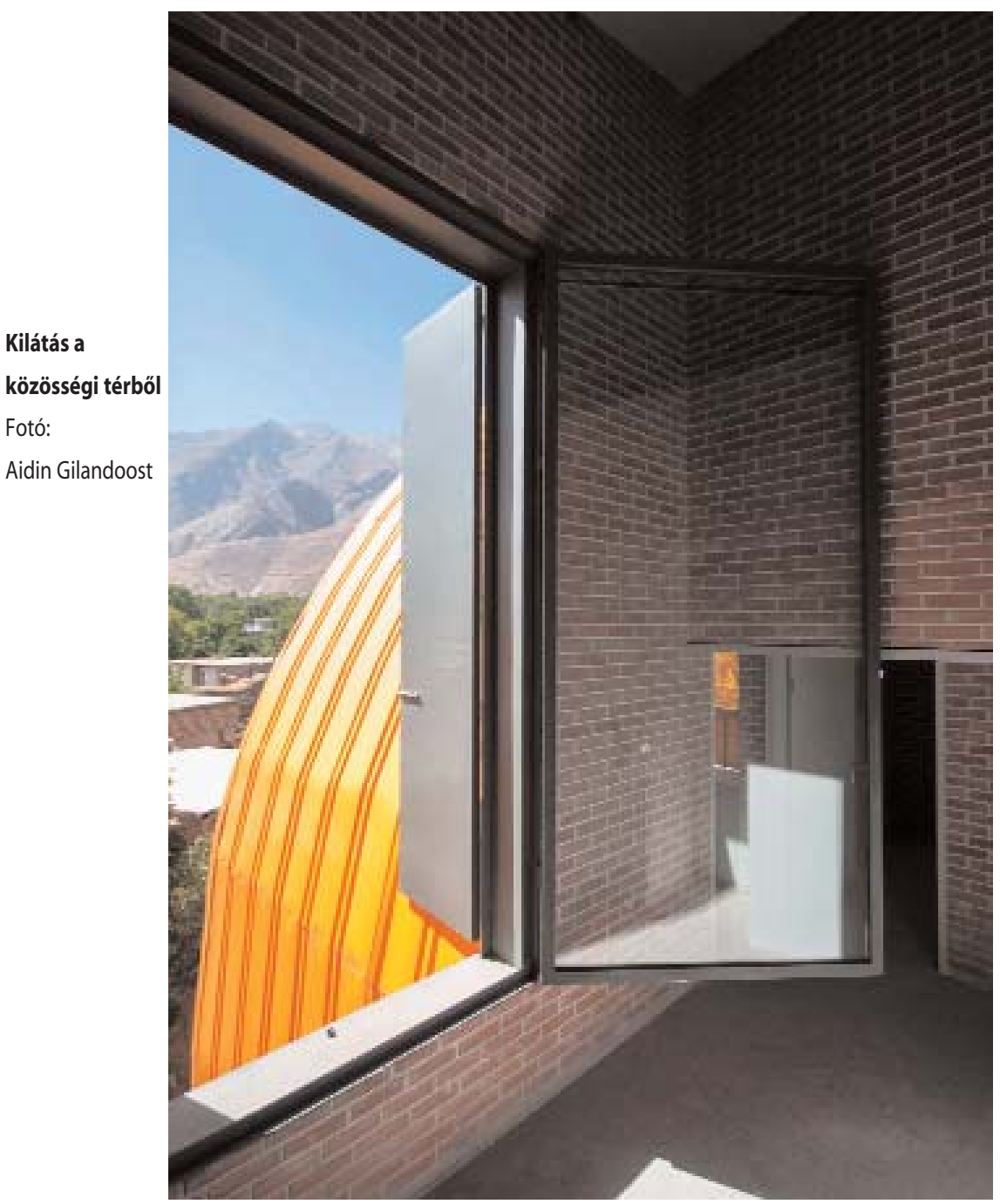

mindenki biztonsággal és szabadsággal rendelkezik - ez az a hely, amibe az állam nem avatkozik be. Ezek a gyermekek azonban lényegében az állam teljes fennhatósága alatt élnek. Szigorú óvatosságra van szükség biztonságuk biztosítása érdekében, az ilyen sérülékeny gyermekeket könnyú megkísérteni, a legtöbb lányban korából adódóan még nem alakulhatott ki az ellenállás a csábításokkal szemben. A sérülékenység bizonyos fokig kizárja őket a polgári életből. Nem engedhetik ki őket a városba szabadon, ehelyett inkább igyekeztek a várost az otthon kézzelfogható közelségébe hozni az erkélyekkel. Az állami tisztviselők határozottan ellenezték ezeket az erkélyeket, és harcoltak, hogy megakadályozzák azok létesítését. A nehezen feloldódó tárgyalások végül kompromisszumot eredményeztek: az erkélyek megépülhettek, de a tisztviselők megnyugtatására elhúzható függönyök, egyfajta „hidzsábok” takarják őket.

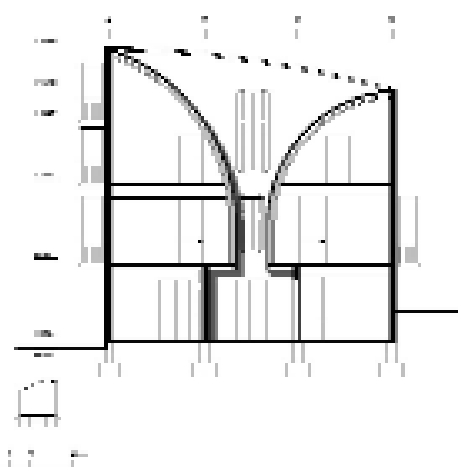

A hidzsáb a muszlim nők fejét takaró kendő (a csador a teljes testet takaró kendőszerú ruhadarabot jelenti), de a kifejezés az iszlámban szerénységre, titoktartásra, erkölcsösségre is utal. Iránban Reza Pahlavi sah 1936-ban betiltotta viseletét, ezzel is segítve az ország modernizációját, majd az 1979-es iszlám forradalom kötelezővé tette a hajat és a testet teljesen takaró viselet nyilvános helyen való viselését. Nincs előírás a hidzsáb színére, az idősebbek kedvelik inkább a feketét, a fiatalok világosabb árnyalatokat, gyakran mintás anyagokat öltenek magukra. Az elmúlt hónapokban felerősödött a nők lázadása a törvényben előírt ruházat ellen, számos nő került börtönbe emiatt. Évente 3-4 millió nő kap figyelmeztetést azért, mert nem az eloírásoknak megfelelő fejkendőt visel, sok esetben csak mert félrecsúszott a kendője.

A függönyök, hasonlóan az egykori polgárházakhoz, kissé előretolt határvonalat képeznek a andaruni és a biruni, azaz a zárt privátszféra és a külvilág, a nők és a férfiak területe között. [3] Az erkély a befogadás és a kirekesztés közötti átmeneti, megengedő térré vált. A lányok örömmel vették birtokba az erkélyeket, mert egy olyan helyet fedeztek fel, ahol önmaguk lehetnek egy- 

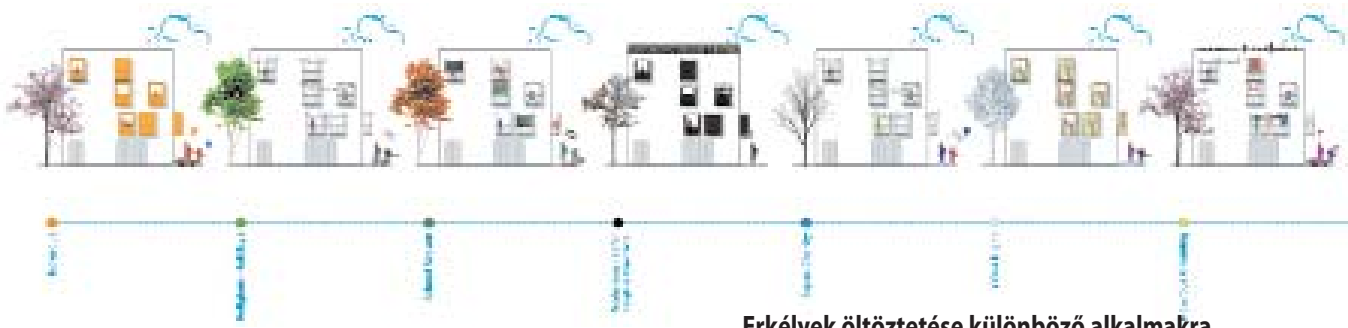

egy pillanatra. Az erkélyt öltöztethetik maguk helyett, a különböző alkalmakhoz illően önmagukat kifejezve cserélhetik le alkalmanként a narancssárga lepleket, ezzel személyesen is megjelennek a városban. A színválasztás nem véletlen, ebben a korosztályban a lányok kifejezetten kötődnek a meleg színekhez. [4] A gyász vagy a vigasság ünnepein, vagy a változó évszakokon keresztül az erkélyeik kendőzetének megváltoztatásával fejezik ki magukat, a város kulturális idővonalával összhangban, a cserélődő textilekkel a cenzúra esztétikáját megjelenítve.

A Habitat for Orphan Girls néven ismertté vált, 2018ban az Architectural Review lakóépület kategóriában első díjas projekt az első ilyen jellegű Iránban. Az alternatív megközelítés akár mintául is szolgálhat a jövőben a család fogalmának újraértelmezéseként az árvák számára, és nemcsak Iránban, hiszen az UNICEF becslése [5] szerint 140 millió gyerek él szülők nélkül a világon. Al-

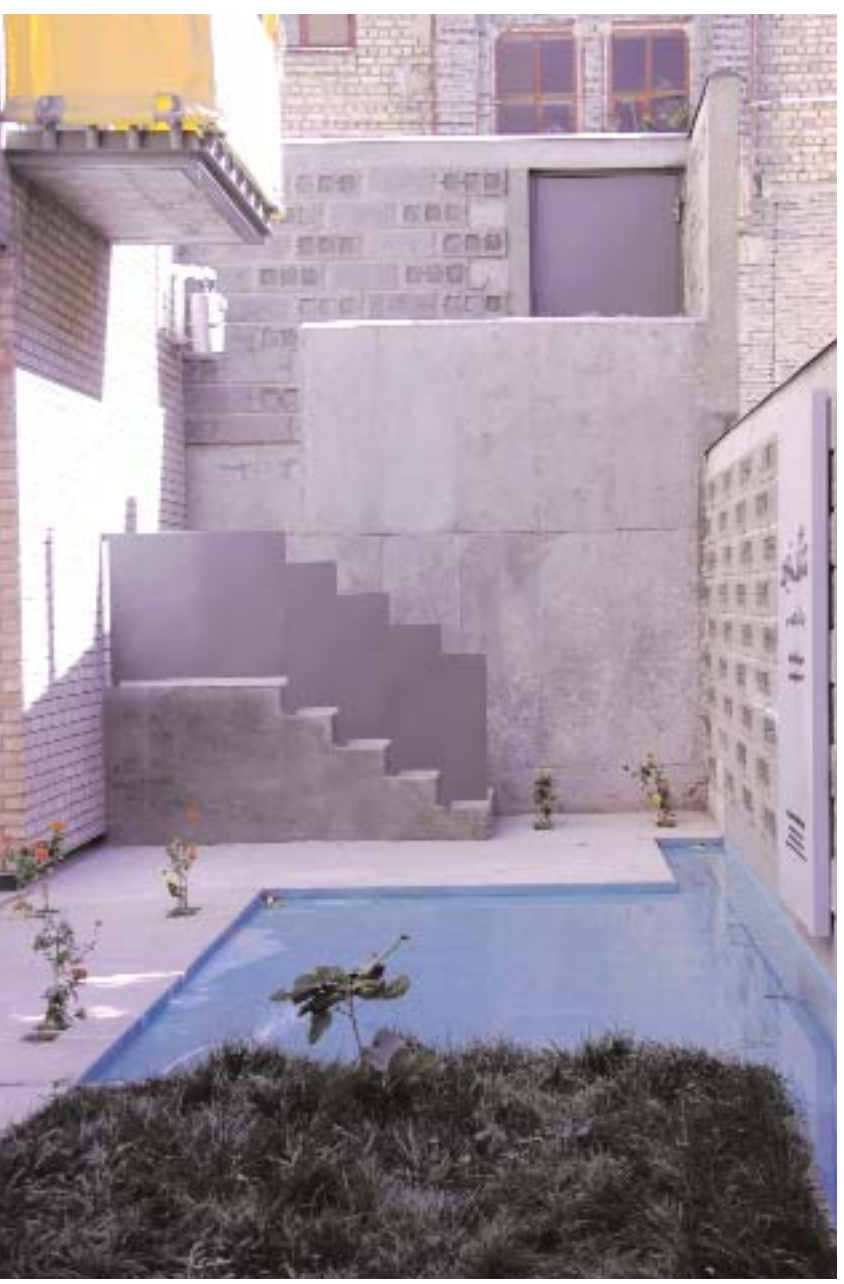

Erkélyek öltöztetése különböző alkalmakra

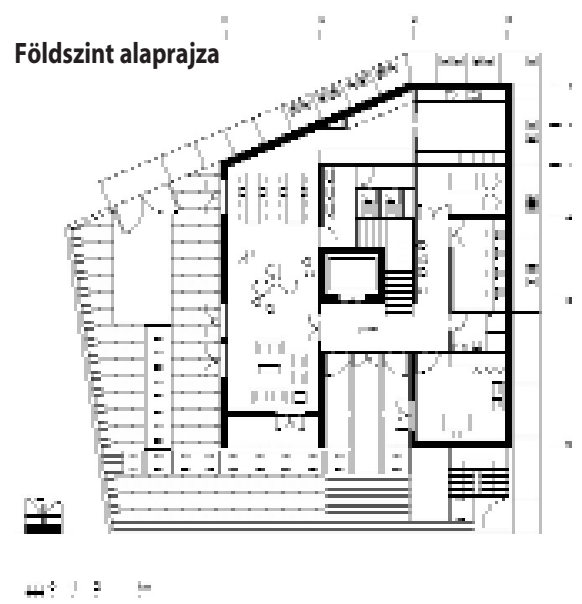

Második emelet alaprajza

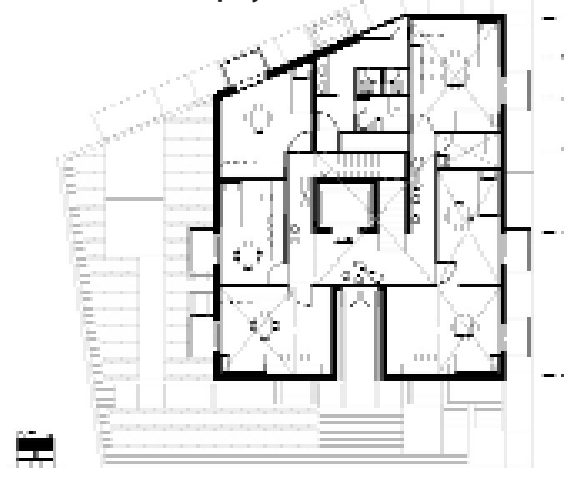

kotói anélkül hoztak létre újat, hogy megtagadták volna a múltat. Az iráni éghajlati viszonyokra választ adó hagyományos perzsa építészet lényege ott van falaiban. A helyi stílus nem a hagyományos formák vagy részletek integrálását jelenti annak érdekében, hogy megvalósuljon a „perzsa identitás”. A múlthoz való hűség a kontextushoz történő közvetett kapcsolódással valósult meg. Az épület tiltásból nyer erényt, magában hordozza az ország történelmének lenyomatát, Khansar múemlék épületeinek fakó téglafalait, a huszadik századi Irán európai mintákat követő modern korszakának hatását és a napjainkban a Közel-Keleten is új utakat kereső „világépítészet" kreativitását a vallási kötelmek enyhítése érdekében.

\section{Sebes Péter}

\section{Irodalom / References}

1 Sfera, Adonis - Osorio, Carolina: „Thinking Pattern East and West", SOJ Psychology Vol 1, No 4 (2014), pp 1-2, DOI: $<10.15226 / 2374-6874 / 1 / 4 / 00117>$.

2 Khanbabaei, Anahita: „Designing orphanage with the approach of creating sense of belonging to the environment", The Turkish Online Journal of Design, Art and Communication, 2016 Special Edition, pp 1357-67, DOI: <10.7456/1060AGSE/020>.

3 Sykes, Ella Constance: „Domestic Life in Persia", Journal of the Society of Arts, London, Vol 50 (1902), p 96.

4 Anbari, Maral - Soltanzadeh, Hossein:

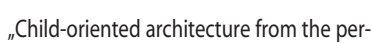
spective of environmental psychology", European Online Journal of Natural and Social Sciences (2015), Vol 3, No 3, pp 137-144, hozzáférhető: <http://europeanscience.com/eojnss_proc/article/view/446 $3 / 2185>$.

5 www.unicef.org [honlap], hozzáférhető: <https://www.unicef.org/media/media_45 279.html>

\section{A víztükör átjáró ég és föld között} Fotó: Soroush Majidi

\section{Építész: ZAV Architects}

Projektteam: Mohamadreza Ghodousi, Parsa Ardam, Fatemeh Rezaie, Fakhr-e-Astane, Mahshid Gharibi, Seyed Hossein Hejrati, Golnaz Bahrami, Sara Jafari 


\section{$\mathrm{A}$}

\section{SUGÁR, Péter: THE POETICS OF PRACTICE} Citation: Metszet, Vol 10, No 2 (2019), pp 14-21, DOI: 10.33268/Met.2019.2.1

JAZZ LOFT AQUINCUM APARTMENTS, ÓBUDA, HUNGARY

ARCHITECTS - GÁBOR TURÁNYI and BENCE TURÁNYI

Covering a period of almost thirteen years involvement with this project father and son architects have worked to find a fitting harmony between the old and new. Taking a long abandoned redbrick industrial building and completing the theme of brick construction to the exterior whilst inserting a contemporary reinforced concrete interior enforces these ideas. The metal cladding used on the exterior to roofs and balconies helps to offset the brickwork and confirm the design philosophy of this architectural practice.

\section{AMICHAY, Eva: PAWSON IN JAFFA}

\section{Citation: Metszet, Vol 10, No 2 (2019), pp 22-25, DOI: 10.33268/Met.2019.2.2}

THE JAFFA HOTEL AND RESIDENCES, TEL-AVIV, ISRAEL

ARCHITECT - JOHN PAWSON

In Tel-Aviv, The City That Never Sleeps, how does one create a place to relax in relative calm? A former convent and hospital has been refurbished, including careful restoration of archaeological structures to create a new spatial character via the combined use of historical and contemporary furnishing and installations.

\section{WARE-NAGY, Orsolya: CAREFUL EXTRAVAGANCE}

\section{Citation: Metszet, Vol 10, № 2 (2019), pp 26-29, DOl: 10.33268/Met.2019.2.3}

ONE ROOM HOTEL, ANTWERP, BELGIUM

ARCHITECTS - DRIESEN, VERSCHUEREN and DEBAETS (DMVA)

It would have been reasonable to take this tiny house, dating back to the 17th century, and simply restore it as a conventional dwelling, instead the client opted to explore new concepts in tourist accommodation. Taking all parts of the structure, both new and old, then painting them white (excluding the floors and entrance door) creates a clean aesthetic suited to short term rentals. This project offers a temporary place of stay to people who wish they had done a similar project but never ant around to it

\section{SEBES, Péter: THE AESTHETICS OF CENSORSHIP}

\section{Citation: Metszet, Vol 10, No 2 (2019), pp 30-33, DOl: 10.33268/Met.2019.2.4} HABITAT OF ORPHAN GIRLS, KHANSAR, IRAN

ARCHITECTS - ZAV ARCHITECTS

There is thought to be 140 million orphans world wide, these citizens have a right to a home and personal identity. This project in Khansar does just that by providing shelter and a true sense of "persian" cultural status. Respecting Iranian traditional laws this building has balconies covered in hijab-like textile awnings which provide the occupants with a sense of privacy and cultural inclusion. Otherwise this project does not attempt any form of grand architectural statement being constructed from locally sourced materials, following in the tradition of an atrium house with a water feature in the garden.

\section{Citation: Metszet, Vol 10, No 2 (2019), pp 34-37, DOl: 10.33268/Met.2019.2.5}

PORTUSHOME GUEST HOUSE, KISDÖRGICSE, HUNGARY

ARCHITECT - BARNA KOVÁCS D.

Should Folklore dictate how an architect designs a building or not? Maybe it is time to deconstruct the idea that traditional techniques can only apply to certain building types or locations. This guest house combines contemporary ideas of comfort and spatial arrangement with traditional, regional, construction skills. The resulting building establishes a new, yet, recognisable typology without falling victim to sentimentality.

\section{WESSELÉNYI-Garay, Andor: EMBROIDERED ARCHITECTURE} Citation: Metszet, Vol 10, № 2 (2019), pp 38-43, DOI: 10.33268/Met.2019.2.6 FAMILY HOME, NAGYKOVÁCSI, HUNGARY ARCHITECT - SZABOLCS DIENES DLA

Modernism questioned the idea of architectural decoration by drawing comparisons to embroidered cushions. Now we live in an age where decoration, although not obviously functional, can be viewed as architectural. This new form of architectural embroidery or embellishment brings with it another sense of worth that reinforces ideas of architectural wealth through visual creativity. Patterned brickwork, stone walls and decorative finishes to metal sheet and concrete all work together to create an architectural entity.

\section{WETTSTEIN, Domonkos: BALATON VILLA}

\section{Citation: Metszet, Vol 10, No 2 (2019), pp 44-47, DOl: 10.33268/Met.2019.2.7} VILLA AT LAKE BALATON, SIÓFOK, HUNGARY ARCHITECT - MIHÁLY CSIKÓS

Traditionally homes found on the bank of Lake Balaton served as summer season only holiday destinations. Now, due to changes in transportation, work-life variations this location is now being sought for all year round living. The question being how to establish a home which serves equally well throughout the year, a more urban typology or a Mediterranean feel?

\section{TARI, Gábor: CAPTIVATED BY WHITE}

Citation: Metszet, Vol 10, No 2 (2019), pp 48-51, DOI: 10.33268/Met.2019.2.8
COLOUR AND ARCHITECTURE AN INTERNATIONAL COMPARISON

ARTICLE BY - Dr. GÁBOR TARI

The question of why so many buildings are finished in white render has been investigated by Dr Tari in order to assess why colour schemes in architecture seem to be limited. Naturally this research touches on the united subjects of form, colour and texture linked to social factors of wealth and building use types. Sadly the result of his work demonstrates that, although seemingly natural materials (brick, stone, wood ) are thought of as being valid for construction, plaster renders usually end up being white or beige due to a lack of colour identity being recognised at an urban planning level. Meanwhile, once colours are used a sense of visual wealth is attained, although pastel tones are preferred.

\section{MEDGYASSZAY, Péter: A „SUSTAINABLE HOUSE"} Citation: Metszet, Vol 10, No 2 (2019), pp 52-55, DOI: 10.33268/Met.2019.2.8 REFURBISHMENT OF A LISTED DWELLING HOUSE

\section{ARCHITECT - PÉTER MEDGYASSZAY}

Ten years after the complete restoration of a listed dwelling house architect Péter Medgyasszay assess progress in terms of construction technology and environmental impact. Amongst his conclusions issues of problems regarding securing thermal insulation, waterproofing and thermal performance have been examined. From an energy point of view this project has been successful despite some technical problems. Current technologies, not available ten years ago, would also benefit this project type. 